\title{
The Use of Minangkabau Proverbs of Contrast Meanings by Minangkabau Society in Medan
}

\author{
Meisuri $^{1}$, Syamsul Bahri ${ }^{2}$ \\ ${ }^{1,2}$ Universitas Negeri Medan, Indonesia \\ meisuriw@yahoo.com
}

\begin{abstract}
The purpose of this study is to find out a complete picture of local wisdom on the use of Minangkabau proverbs that have contrast meanings by the Minangkabau society in Medan North Sumatera, Indonesia. The research used descriptive qualitative method, by conducting interview as well as questionnaires distribution on provided proverbs to a total of 60 respondents from different regions of Minangkabau community, namely Kota Matsum I, II, III and IV. The data were collected and classified based on the various fields of Social Culture, Economy, Politics, Law, and Religion which were then analyzed by interpreting the meaning of contrast contained in the proverbs relating to the customs and traditions they practiced in daily life. It was found that despite the strong evidence on philosophy of cultural values and openness toward the modernization, this people have been consistently using the contrasted-meaning proverbs in their almost all-different-contexts of conversation. It also showed that the use of Minangkabau language as local language, has contributed to the field of language and literature studies, especially in the area of ethnical proverb that could enrich the repertoire of Indonesian, as the national language.
\end{abstract}

Keywords: Local wisdom; Minangkabau proverbs; contrast meaning.

\section{Introduction}

Minangkabau language is one of the local languages derived from the Malay that has enriched the Indonesian. As a tool of communication and thinking, the language will be used to transform the people identity within the context of a particular cultural situation and context, and has variety of dialects that are well maintained by their speakers which is written and represented in the form of a proverb. However, recent sociolinguistic studies show that there have been shifting phenomenon of the existence and position of some local languages in Indonesia, including Minangkabau. Indonesian language seems to have taken the role of the local languages in various domains, as for the people positive attitude towards the national language.

The fact that it spreads to almost all parts of the region in Indonesia and has brought about the attitude and pattern of wander of Minangkabau people in West Sumatra to other areas including to Medan, North Sumatra. However, the speakers still preserve their mother language wherever they are, as to the one proverb that they always hold firmly: "dima bumi dipijak, disinan langik dijunjuang", which means is to give advice or teachings for Minangkabau people that wherever we are, although we are still wandering in other countries, the customs and the languages should always be preserved.

In preserving their native language, Minangkabau people who migrate to various areas, always communicate using the local language in almost all occasions; in the family, daily social life, and events or customs associations. It has been well known that this group of people is not the commonly-direct spoken people, but always use metaphor or figurative language in their talking, particularly in the form of proverbs. The accuracy in abstracting the forms, character, and human values, however, greatly enriches their knowledge in communicating and producing forms of figurative expression (Oktavianus, 2015). So we can say that the figurative language in speaking is the identity marker of Minangkabau people. The figurative in speech could produce a beautiful proverbial expression and is pleasant to hear by the speaker's opponent. 
This maxim is one of the types of proverbs represented in figurative sentence that contains elements of advice or teachings. However, it is not common to find other society uses a contrasting or contradictory proverb in other ethnic groups, such as the maxim 'takuruang andak di luar, tahimpik andak di ateh' (enclosed to the outside, oppressed in the above). This proverb contains contrasting meanings, be enclosed is usually inside, and not outside, while being oppressed is supposed to be below something, and not above it. This contrasted meaning proverb is expressed to insinuate someone who is untruly, a person who acts arbitrarily intending to advise not to behave with the arbitrary. Many other expressions of Minangkabau proverbs that mean contrast can be traced and it, therefore, become the objective of this research which was considered an interesting issue to be explored.

What is proverb? Diradjo (1912) defines "all the words that are arranged into sentences, so that it contains the meaning, the figurative expression, and the like in it". The words were compiled and collected by the elders of old, to be a way of teaching to all of us our grandchildren to know and clever think for themselves, for the salvation of life in this world. Marwoto \& Witdarmono (2004) further adds that besides its functions to refresh the direction of a person's idea, it is something expressed normatively functions with legal, social, psychological, physical, material and message sanctions. The messages conveyed were moral, ethnic, religious, or prohibited, teachings, messages of myth, exemplary, and appeals.

There are many other studies on the Minangkabau proverb and maxim. By looking at the progress of previous studies, the research was intended to describe the 'Use of Minangkabau Proverb of contrast meaning by Minangkabau Society in Medan'.

In line with the efforts of the development, coaching, upgrading, and preservation of local languages, this research is one of the many ways to respond to the realization of that direction in reference to the statement of Oktavianus (2015) that figurative is the culture of the Minangkabau society and is almost commonly found in the phrase of Minangkabau language (Saleh, 1999).

There are many other interesting studies on Minangkabau proverb and maxim. Honeck and Colston (2000) point out "proverb meaning should not be the focus but, rather, the proverb performances. Yet he confirms that this process will entail a variety of issues in the many areas of categorization. That is true in a case of giving particular intentions, especially for those who have been familiar with the speakers' habit or tradition. Therefore, once a person been exposure to this unique situation and context, she would easily interpret the real meaning of the sentence, because the overall proverb understanding process obtains both in irrelevant and relevant contexts (Temple \& Honeck, 1999). He also questions if the comprehension of a proverb's figurative meaning should first require the development of a literal meaning. Presentation of proverbs in irrelevant-context situations presents an interesting set of problems for those who do not recognize the message in the seemingly-literal meaning. It is necessary for them to able to construct a newer and more appropriate meaning.

One of the most recent studies on the Minangkabau proverb was done by Noverita (2018) who analyzed the meanings of its classical proverb using the Proverb Tree Model and found that there was a close relationship between the practice of traditions and religion implemented by the Minangkabau people in their daily life. They believed that the power of religion signifies and that tradition and religion must be carried out by the self as well as used by society, for bringing goodness (p.118).

Despite the uniqueness of the cultural perceptions of proverb, Friedman,et al.(2006) claim that most members of the Asian cultures show a greater preferences than Euro-Americans for proverbs expressing paradox across cultures, especially the dialectical proverbs to be as 
likable, wise, and poetic as the non-dialectical proverbs. It is not only the poetical and dialectical aspects that to be the concern of some scholar, but also the different context and situation as well as the relevant cultural values towards the most appropriate meanings (Bahri, 2001).

This research is expected to be useful in the development, improvement, and development of local languages especially Minangkabau language and also contributed in the field of study of language and local literature, especially in the field of Minangkabau maxim that can enrich the repertoire of Indonesian language as a national one. How does a complete portrait or description of local wisdom on the use of the Minangkabau Proverb that means a contrast to the context of socio-cultural, economic, law, political and religious situations?

\section{Review of Literature}

This study applied the contrast theory that emphasizes the opposite meaning encountered in an expression or utterance of sentence. According to Alexander (1963), contrast is a part of structural devices that has two completely opposite pictures side by side. Sometimes the contrast is immediately obvious and sometimes implied. It can be interpreted that contrast is a part of structural tool which has two images that are opposite each other. For example in the poem "The Ancient Mariner on the line 'burst into that silent sea'. The word "burst" is opposite to "silent sea" and "down dropt the breeze, the sails dropt down". The word "breeze" is the opposite of "the sail dropt down" condition. The conditions and situations opposite the wind that blow quietly in the breeze create a shipwreck and drown in a sea of calm and broad. Two opposite situations are portrayed in the poetry literature giving the value of its own beauty and curiosity to its readers. This parallel syntax of antithesis supports the contrast not only presented in a visual but also in an aural way (Fahnestock, 1999).

\subsection{Contradict Figure of Speech}

Proverb could be defined as a short, catchy saying that give some piece of advice or make a general observation about a common occurrence (Fanany \& Fanany, 2003). The proverb, on the other hand, must be independent and metaphorical utterances containing tradition and advice that bring goodness toward others. Value can be attached to or part of things or the character of human beings; such as the value of money, humanity, culture, and ideology (Oktavianus, 2015). Despite the literal meaning contained in the proverbs, the intended value will indicate the meaning of different context of situation. In a social context, for example, the interpretation should be relevant to the goal or message of the speaker's utterances.

However, some experts agree that the meaning of Minangkabau proverbs have shown significant shifts from basic to metaphorical meaning. Since the meaning of Minangkabau proverbs are contextual (Octavianus, 2015; Navis, 1996)), it would also be possible that the meaning, pragmatically contradict to the utterances. When a mother finds her son putting dirt into his toy car, she is very upset, but will say instead: "duh, bagus...bagus sekali, nak..."!. (oh, very...very good, son"). The mother expressed her feeling of concern or anger by uttering a very different statement. We assume that this contradictory expression, is supposed to be also understood by the son for he knows well that his mother is use to saying the same or similar expression to criticize him. In the Minangkabau proverbs, these phenomena have long been occurred, and usually in the use of figurative speech.

Waridah (2013: 337) classifies the contradict figure of speech into five types, namely: 
1. Antithesis is a language that expresses a purpose by using opposite words. Example: Before deciding something, you should first consider the good or bad.

2. A paradox is a style of language to express two things that seem to contradict each other but in fact, both are true.

Example: His soul feels lonely amid the frenzied party.

3. Oxymoron is a style of language that contains contradictions by using the opposite words in the same phrase.

Example: failure is a delayed success

4. Anachronism is a style of language that contains incompatibility between events with time. Example: The Company managed to track the existence of Si Pitung because of the help of GPS technology

5. Interments contradiction is a style of language that contains a denial of the aforementioned statement.

Example: The problems that exist in this country will never be completed unless the government is paying great attention to every issue.

\subsection{Local Wisdom}

Local wisdom is a wise idea. It is local knowledge that is wise, full of wisdom, good and virtuous value, owned, led and implemented by members of the community (Sibarani 2014: 114). As an oral or cultural tradition passed on from one generation to the next, local wisdom contains the order of social life in various aspects, which can shape the life of society.

Local wisdom is extracted from the noble culture of a society, applied by the community of its speakers, and is also used to regulate the living order of society and also as social control. Local wisdom that is still being developed in various regions gives characteristic of its culture in certain regions and communities. The value of the cultural value possessed in this local wisdom can provide something that directs a society how to behave, speak and act in a society. The value of this noble teaching must be developed to preserve the order and pattern of life of a wiser, positive and cultured society.

\section{Research Methods}

The study was conducted by using descriptive qualitative method that can be interpreted as a problem-solving procedure investigated by describing the state of the object of research at present based on the facts that appear or as it is. In this study, the use of such methods can provide a complete and accurate description of local wisdom on the use of proverbs that mean contrast by the Minangkabau society in Medan.

The data of this study were gathered by administering a friendly-technique interview with 4 senior Minangkabau people in the community, distributing survey questionnaires to 60 respondents of various backgrounds of ( age, education, and social status), and also from the comprehensive literature review. The population was limited to only those residing in Kota Matsum I, II, III, and IV, that these four urban villages could represent this ethnic people in Medan. The majority (75\%) population of these areas is Minangkabau people. 


\section{Discussion}

\subsection{Research Results}

The Minangkabau Proverb that Means Contrast in Various Contexts

1. Socio-Cultural Context

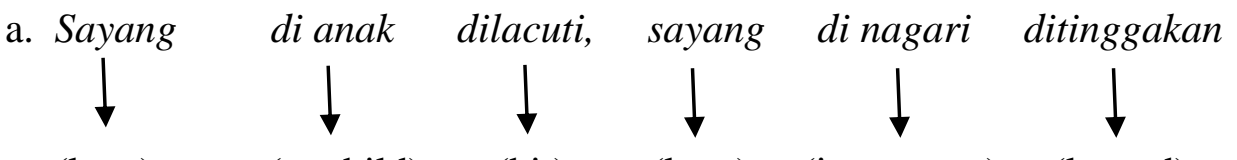
(love)
(to child)
(hit)
(love)
(leaved)

(If we love the child, hit him if he did not do good, if we love the country, it should be abandoned to seek for the fortune and knowledge that will be donated sincerely to this country later.)

sayang dianak > dilacuti, sayang di nagari $><$ ditinggakan

This proverb teaches the Minangkabau people that it is not good to spoil a child. If a child makes a mistake there must be punishment in order not to repeat the same deeds.

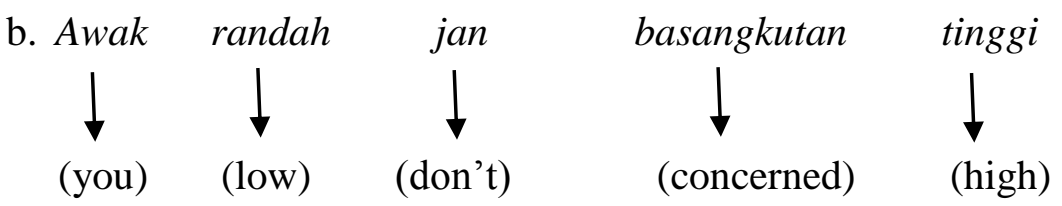

(In life we must understand of being loved, if we from the bottom do not pretend like the rich and arrogant)

Randah > tinggi

This proverb gives teachings and advice to the Minangkabau Society that in this life we must know ourselves and be good at bringing themselves in various situations of life. If we are from the bottom do not pretend to be arrogant and act like the rich and forget the real conditions.

c. Abiah pandakian ado panurunan, abiah panurunan ado pandakian

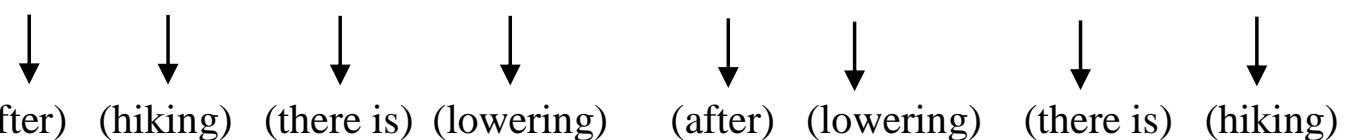

(after) (hiking) (there is) (lowering) (after) (lowering) (there is) (hiking)

(Behind the distress there is the ease, behind the suffering there is pleasure)

\section{Pandakian $>\langle$ panurunan , panurunan $\rangle\langle$ pandakian}

This proverb contains the advice and teachings of life for the Minangkabau people that in every difficulty there must be amenity. For every problem there must be a solution. The maxim that contains element of this advice provides motivation for the people who try, who like to wander outside of their own country to continue the spirit and optimistic in the act although difficulties and problems are always faced both economically and socially.

2. Economic Context

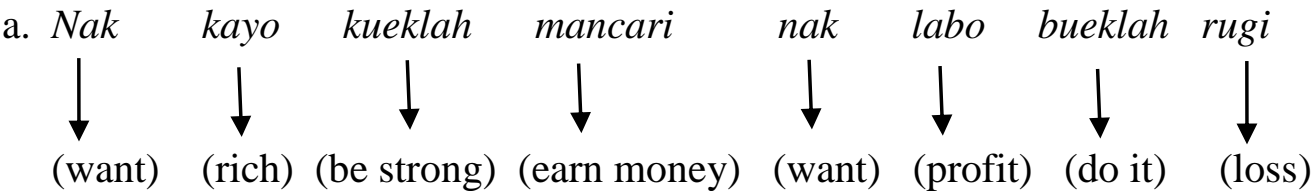

(Satisfactory results will be obtained through hard work and sacrifice) 


\section{nak labo > bueklah rugi}

This proverb teaches the Minangkabau people that in trying or running a business, we must sacrifice first both material and time. The sacrifice of time and hard work can produce results to make a financially better change that can change the family welfare.

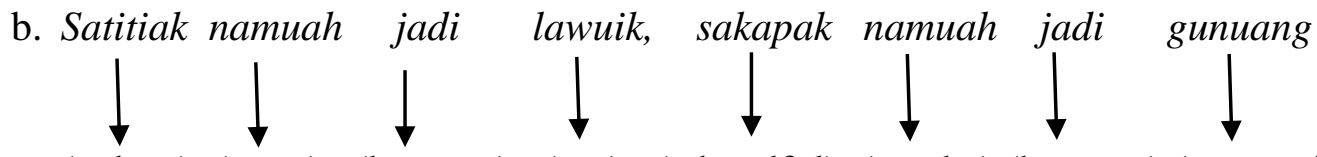

(a drop) (want) (become) (sea) (a handful) (can be) (become) (mountain)

(If we save little by little later we will have more savings)

satitiak > < lawuik, sakapak > < gunuang

This proverb teaches the Minangkabau people that to get a better future, they should get used to saving early, little by little later it will be a hill. Saving is a noble trait that thinks about the future and shapes the attitude away from waste. The Minangkabau people are deeply committed to the teachings and rules of the Islamic religion where simple life should take precedence and stay away from the wasteful nature, one way is to save.

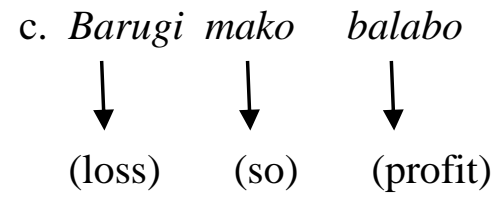

(Everyone should dare to try to get results)

Barugi > balabo

This proverb contains advise to the Minangkabau people that in trying or trading should dare to sacrifice. Raise the capital of the business first and then get a profit from the hard work or effort that is done. Dare to sacrifice, and dare to work hard on the business is the largest capitalized which will shape the success of a person for himself, the family and even the surrounding community.

3. Political Context

a. Bulek jangan basuduik, picak jangan basandiang

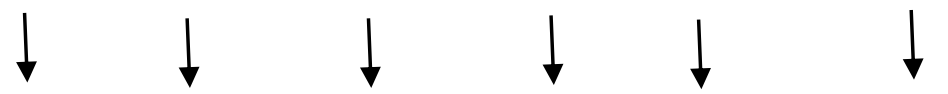

(round) (don't) (has angles) (flat) (dont) (side by side)

(The unanimous thing of being taken without sincerity leads to unfavorable things because some people decide to be forced to do so)

Bulek > < basuduik, picak > < basandiang

This Minangkabau proverb teaches that in making decisions or unanimous words should be done sincerely without any coercion from any side. The sincerity we provide can give good togetherness in a forum. There is no compelled in giving opinions or decisions for the sake of an action which will be done together and to achieve common goals as well.

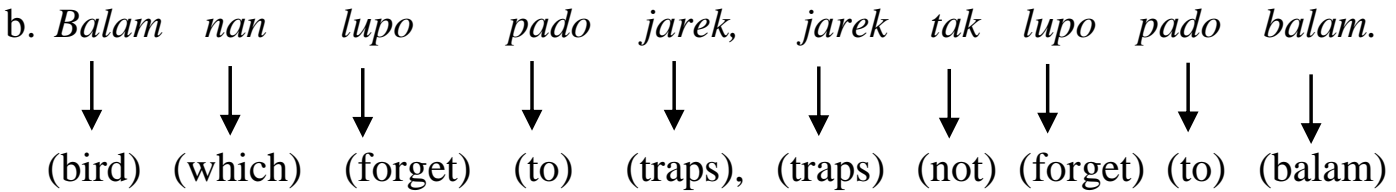
(In an atmosphere of war we should always be in the vigilance of every possibility) 


\section{Balam nan lupo pado jarek > < jarek tak lupo pado balam}

This proverb teaches the Minangkabau society that in the war conditions the vigilant action must be kept on standby because at any time when the guard is not even the enemy can beat us. This alertness should be applied to the condition anytime so that if there are other parties who will do no good we can avoid it.
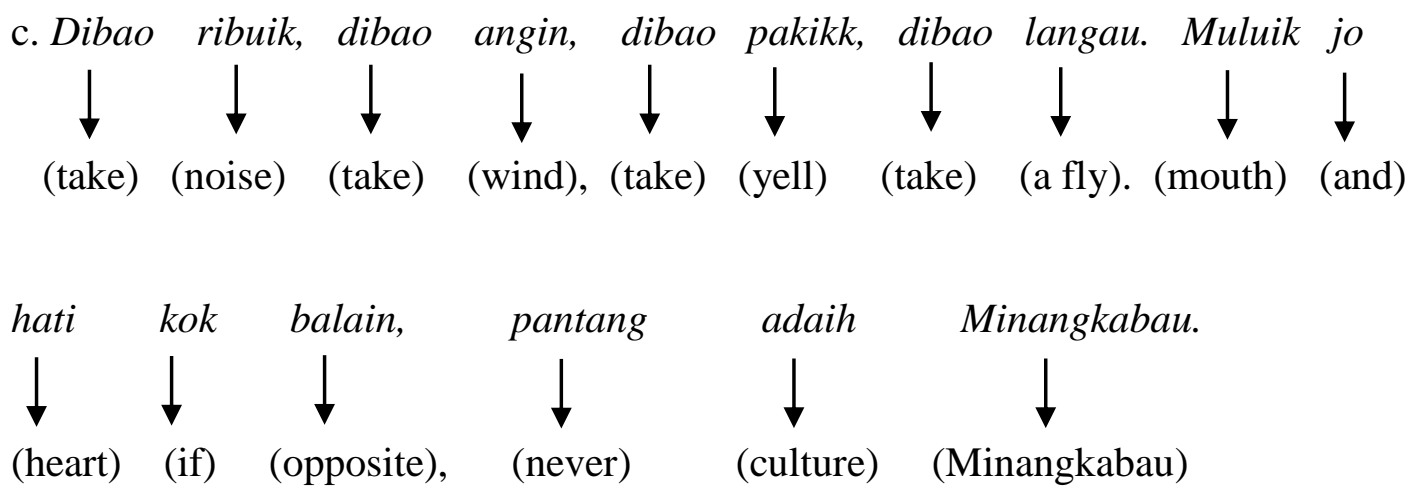

(Different in the mouth and in the heart, neither the characteristic of a leader, nor the customary teachings of Minangkabau)

Muluik > < hati balain

This proverb gives teachings and advice to the people that when speaking should hold firmly to the heart, and be honest. We must avoid other expressions "different in heart and the mouth". As Minangkabau people who are religious and honest, must be upheld and always applied in daily life. And it is a must for a leader who become community leaders, must always act on honesty and behave in accordance with what is hearted, what is spoken must be relevant in order to provide a model example for the surrounding community.

4. Law Context

a. Baruak dirimbo

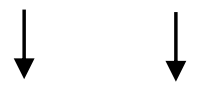

(monkey) (in jungle) disusukan,

anak

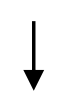

(breast fed), (child) dipangku

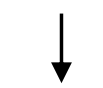

(on lap)

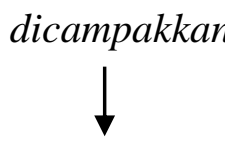

(dumped),

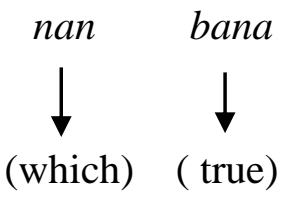

dianjak tidak.
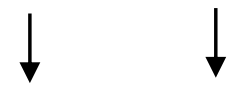

(changed) (not)

(The truth and justice are not well considered, but used in punishment)

anak dipangku > < dicampakkan, nan bana > < dianjak tidak

This proverb advises the Minangkabau community that in acting and behaving, the truth and justice are what are enforced in law.

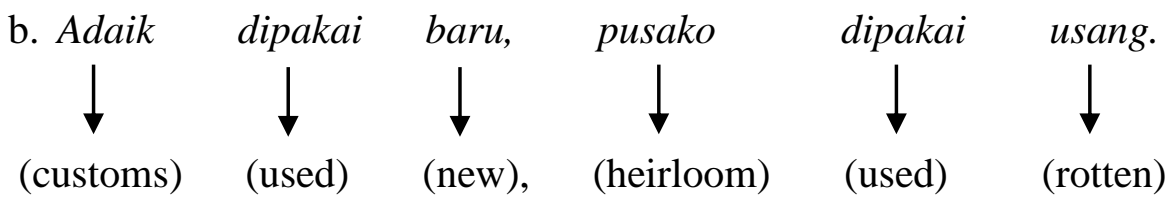


(Custom, especially for Minangkabau people should not be eaten by the times. Not rotten in the rain, not cracking in the hedge, while the heritage is getting less and less and even run out if not maintained properly.)

Adaik dipakaibaru> < pusako dipakai usang.

This proverb provides teachings and advice for the Minangkabau society that wherever you are, you should still uphold the customs and traditions of 'Dima bumi dipijak disitu langik dijianuang' (in Rome do what the Romans do) is a term that reminds the Minangkabau people to always uphold the customs and tradition in their daily life. Many of them leave their home and wander to start new life, but their tradition and customs will never be fade away and even keep it growing outside of the country.

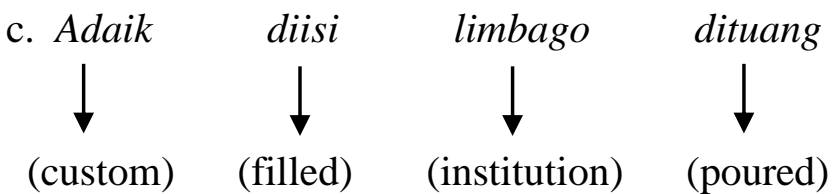

(In doing something, the people must always stick to the regulated-custom or according to what is already been familiar with and solidified)

Adaik diisi > < limbago dituang

This proverb gives teachings and advice to the people that in this life we should do something in accordance with what has been culturally determined or according to what has been dyed. The custom continues to be preserved and developed in the steps and actions of family and community.

5. Religion Context

a. Jan bakato iyo namun hati bakato indak, hiduik jauah dari agamo

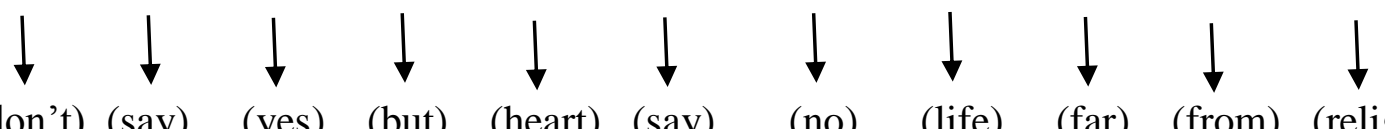

(don't) (say) (yes) (but) (heart) (say) (no) (life) (far) (from) (religion)

(In life we must hold firmly to the teachings of religion and always harmonize between words and deeds).

bakato iyo > < hati bakato indak

The above proverb teaches the Minag people to always show and keep a good manner in speaking, be natural without any pretending. That human must adhere to religious teachings where the heart, speech and action must be aligned.

b. Sabagai umaik Islam randahkan diri, tinggikan cito dan baniek ka tanah suci.

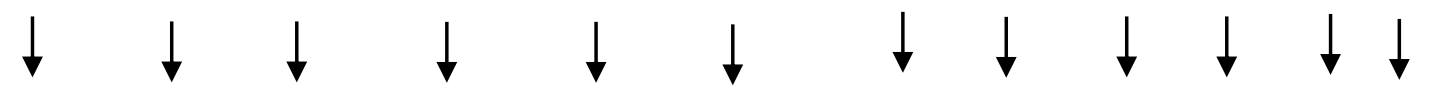

(as) (umat) ( Islam) (demean)(yourself)(exalt)(ambition)(and)(intend)(to) (Holy-land) (As Moslem, be humble character, applied in our daily life. But our adherence to try and pursue ideals should be as high as possible in order to carry out the intention to fulfill the fifth pillars of Islam, to do the pilgrimage to the holy land)

Rendahkan diri > < tinggikan cito

This proverb provides teachings and advice to the people that we should be humble but have a high spirit to try to rely on expectations as high as possible and pursue success in order to perform the pilgrimage. 
c. Bilo bapegang jo adaik dan agamo makolawuik nan lueh tak barombak,

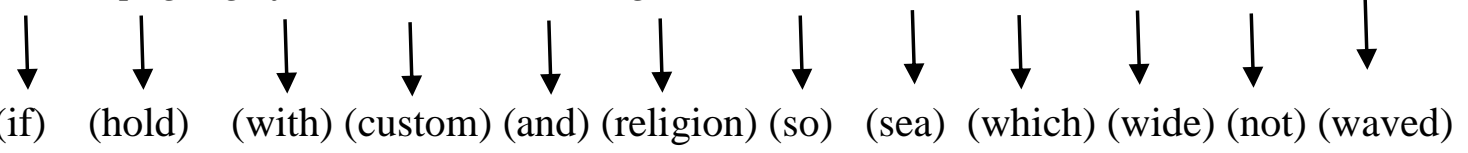

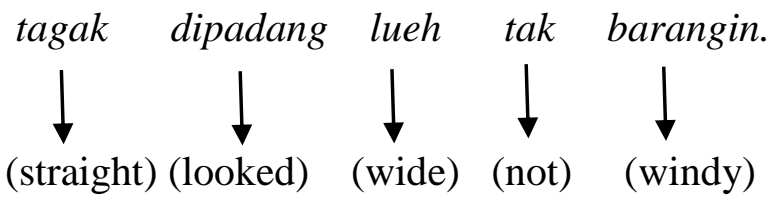

(In life we should adhere to customs and religion even though problems come and go but the faith and mental strength will keep us more calm, given salvation by Allah).

Lawuik nan lueh > < tak barombak

This Minangkabau proverb teaches that in life the people must continue to adhere to customs and religion in order to gain full guide and strength in facing the problems of life.

\section{Conclusion}

From this research it can be concluded that Minangkabau people use proverbs as a means of teaching moral and cultural values to their people. The verbal structure that placed contrasted or opposed terms in parallel or balanced cola or phrases, yet this figure antithesis, still met both syntactic and semantic requirements (Fahnestock 1999).

Minangkabau proverb of contrast meaning used by Minangkabau society was that of satirical sentence which at the same time gave the element of advice. The example in the sentence 'bulek (round) is not basuduik (angle), picak (thin) is not basandiang' (layers), which encountered the meaning of contrast between bulek> <basuduik, which can be a sarcastic sentence that also contained elements of advice that if someone has agreed or unanimous, he must be sincere and on the will of one's own conscience and not the compulsive element. So when the word unanimous has been decided, there is no more discordant phrase behind the decision. The results of this study showed that Minangkabau proverbs that have contrasting meaning occurred and used by the Minangkabau society in Medan classified into some context of situations; ie socio-cultural example, economic context, legal context, political context, and religious context. This finding was in parallel with the result of analysis on some cases of figure in the media that show how textual or visual pairs also formed an antithesis or a contrast meaning (Belle, 2009).

All of these were representations or descriptions of the customs, cultures, attitudes and ideologies of the Minangkabau people. The habits in attitude and language that tend to express the language in contrary meaning in a situation or context has become a hallmark of Minangkabau society. It can be taken example of a context when a mother who is annoyed to see her child, he will be sent out the phrase 'rancak bana parangai waang tu yo' (means 'what a good manner?). The word 'rancak' in this context is not a pretty 'beautiful' meaning, but has the opposite meaning of the context, a mother who does not like the actions or manner of her child and rebukes directly with contrasting words.

Minangkabau proverb that means contrast was occurring in the context of 5 situations of social cultural, economic, legal, political and religious context. It was revealed that the sociocultural context encountered more proverbs with the expressions meaningful contrast. It is also asserted in social interaction among fellow individuals in the community who were always 
linked with a proverb that means contrast. Communicate among each other in the form of a social interaction could not be separated from the practice of tradition, customs, and culture. This contrast-meaning proverb is also considered as one of distinctive value of Minangkabau society in figurative language that reflects customs and culture.

\section{References}

Bahri, S. (2001). Inteferensi Bahasa Minangkabaukabau dalam Bahasa Indonesia pada Masyarakat Minangkabau Perantau di Medan. Medan: Universitas Sumatera Utara.

Belle, H, V. (2009). Playing with Oppositions. Verbal and visual antithesis in the media. In: J. Ritola (Ed.), Argument Cultures: Proceedings of OSSA 09, CD-ROM (1-13), Windsor, ON: OSSA.

Diradjo, D. S. (1912). Minangkabau Proverb. First Volume. Batoe Sangkar: Tandjoeng Soengajang.

Fahnestock, J. (1999). Rhetorical Figures in Science. New Yor /Oxford: Oxford University Press.

Fanany, I., \& Rebecca, F. (2003). Wisdom of the Malay Proverbs. Kuala Lumpur: Dewan Bahasa dan Pustaka.

Friedman, M., Chen, H.-C., \& Vaid, J. (2006). Proverb Preferences Across Cultures: Dialecticality or Poeticality. Psychonomic Bulletin \& Review , 353-359.

Honeck, R., \& Colston, H. L. (2000). A Proverb in Mind: The Cognitive Science of Proverbial Wit and Wisdom. Journal of Pragmatics , 628-638.

Marwoto, B. J., \& Witdarmono. (2004). Proverbia Latina. Jakarta: Book of Compass.

Nafis, A. (1996). Peribahasa Minangkabau . Jakarta: PT. Intermasa.

Noverita, D. (2018). Semantic Analysis of the Minangkabaukabau Classical Proverb Based on the Model of the Proverb Tree. International Journal of Linguistics , 108-121.

Oktavianus. (2015). Meaning and Value in Minangkabaukabau Proverb. Jurnal Tutur, 103-115.

Saleh, A., A. (1999). Ungkapan Minangkabaukabau. Laporan Penelitian oleh Lembaga Kerapatan Adat Alam Minangkabaukabau Padang.

Sibarani, R. (2014). Kearifan Lokal Hakikat, Peran, dan Metode Tradisi Lisan. Jakarta: Asosiasi Tradisi Lisan (ATL).

Temple, J. G., \& Honeck, R. F. (1999). Proverb Comprehension: The Primacy of Literal Meaning. Journal of Psycholinguistics Research , 43-70.

Waridah, E. (2013). EYD Ejaan yang Disempurnakan \& Seputar Kebahasaan-Indonesia. Jakarta: PT. Kawah Media. 